TITLE:

\title{
Current status and legal/ethical problems in the research use of the tissues of aborted human fetuses in Japan
}

\section{AUTHOR(S):}

Kawasaki, Hidenori; Yamada, Takahiro; Wada, Takahito; Kosugi, Shinji

\section{CITATION:}

Kawasaki, Hidenori ...[et al]. Current status and legal/ethical problems in the research use of the tissues of aborted human fetuses in Japan. Congenital anomalies 2020, 60: 166-174

\section{ISSUE DATE:}

2020-11

URL:

http://hdl.handle.net/2433/259190

\section{RIGHT:}

This is the peer reviewed version of the following article: ['Congenital anomalies', 60(6), 166-174], which has been published in final form at https://doi.org/10.1111/cga.12381. This article may be used for non-commercial purposes in accordance with Wiley Terms and Conditions for Use of Self-Archived Versions.; The full-text file will be made open to the public on 14 August 2021 in accordance with publisher's 'Terms and Conditions for Self-Archiving'; This is not the published version. Please cite only the published version.; この論文は出版社版でありません。引用の際には出版社版 をご確認ご利用ください。 
Title: Current status and legal/ethical problems in the research use of the tissues of aborted human fetuses in Japan

Authors: Hidenori Kawasaki, Takahiro Yamada*, Takahito Wada, Shinji Kosugi

Affiliations: Department of Medical Ethics and Medical Genetics, Kyoto University

School of Public Health, Kyoto, Japan

Short title: Problems in research use of fetal tissue

Address of the institutions at which the work was carried out: Same address of Corresponding author

*Corresponding author:

Takahiro Yamada,

Department of Medical Ethics and Medical Genetics, Kyoto University School of Public Health

Yoshidakonoe-cho, Sakyo-ku, Kyoto 606-8501, Japan.

Tel: +81-75-753-9464

FAX: +81-75-753-4649

E-mail: taka0197@kuhp.kyoto-u.ac.jp 


\section{Abstract}

Background

To date there is no law regulating the research use of human aborted fetuses in Japan.

\section{Objective}

The aim was to review the current status with historical background and legal/ethical problems limiting the research use of the tissues of aborted human fetuses.

Method

We reviewed literature via PubMed, Web of Science, Scopus, Japana Centra Revuo Medicina and CiNii, reports from various committees and research groups from Ministry of Health, Labour and Welfare (MHLW), and domestic books.

Results

Aborted human fetal tissues used for research purposes were first documented in the 1920s. The first guideline, the Peel Code was released in 1972. Since then, in Western countries, the research use of aborted fetuses has been less restricted compared with that of embryos, due to the following guidelines outlined by expert groups. Currently, aborted fetal tissues are commercially available for research purposes in the US. In Japan, only four indications are presented in “a public statement permitting research use of deceased fetuses' and 'neonates' organs etc.” (1987). In the 2000s, expert committees 
of the MHLW concluded that research use of human aborted fetuses should be discontinued, and that comprehensive rules and independent regulations should be implemented. This issue has not been discussed in the Japanese legislature since 2003.

Discussion

Establishment of laws and guidelines for this issue is insufficient not only in Japan but also in other countries. It is important to secure transparency for making laws and guidelines and in obtaining public understanding.

\section{Key Words}

Fetal tissue, legal/ethical problem, ELSI, guideline, law 


\section{INTRODUCTION}

For research into medical science or human biology, human tissues or cells are

ideal materials. Although such specimens can be acquired by surgery or biopsy through clinical procedures and pathological autopsy, obtaining a stable supply of fresh optimum materials in good condition is often difficult.

With developments in medicine, animal experiments are indispensable, and animal models of many diseases have been created. In drug development, animal experiments to confirm safety are required before administration to humans. However, side-effects observed in clinical trials are sometimes not observed in animal experiments, because human beings and experimental animals may have different responses to drug administration. Using human materials or human tissues themselves is one of the ways to study human beings precisely, and some data cannot be obtained from materials or organizations other than humans.

For research on human histology and embryology, fetal and/or embryonal tissues are very important materials, ${ }^{1}$ because they are "normal” in most cases. Through the large-scale collection of aborted fetal/embryonal specimens and data, such as the Carnegie Collection ${ }^{2}$ and the Kyoto Collection, ${ }^{3}$ enormous amounts of fundamental knowledge on embryology have been established. To date, some human cell lines of 
fetal origin have been established. The most famous one is transformed embryonal kidney by adenovirus (type5), known as "HEK293”, which was established in $1977 .{ }^{4}$ Cell lines deriving from many kinds of fetal tissues have been created and have contributed extensively to basic research. ${ }^{5}$ In the field of regenerative medicine, the use of aborted fetuses has received much attention. ${ }^{6}$ Because fetal tissues contain many stem cells, which are active in differentiation and growth with less rejection, ${ }^{1,7}$ many transplantations of fetal tissues or cells have been tried for various diseases, especially neurodegenerative disorders. ${ }^{8}$

Nowadays, rapid progress with embryonic stem (ES) cell or induced pluripotent stem (iPS) cell technology is making it possible to supply them as a part of alternatives for human materials for basic research. Even so, ES and iPS cells cannot supply all the materials needed for basic research, and normal embryos or fetuses are still important resources of human tissues.

Although researches using ES cells or iPS cells are increasing, aborted fetuses have been and are still being used for research. When considering the research use of aborted fetuses, we must consider the problem of artificial abortion. In Japan, the penal code, the Maternal Health Act, the Autopsy Law, and ordinances of each local government regulate the handling of human aborted fetus, but no rule exists about the 
research use of aborted fetuses, which may become a major ethical issue. In Japan, the annual number of artificial abortions was 164,621 at 2017 , which was about $17 \%$ of the number of live births. ${ }^{9}$ There is an opinion that research use of aborted fetuses that are destined to be thrown away is an effective use, but is this true?

We conducted a study to identify the current status and historical background about the research application of the tissues of aborted human fetuses not only in Japan but also in other countries, and to identify problems in legal/ethical aspects of this issue.

\section{MATERIALS AND METHODS}

We conducted a search of PubMed, Web of Science, Scopus, the Japana Centra Revuo Medicina (the largest database of Japanese articles), and CiNii (Scholarly and Academic Information Navigator). The search formulas were as follows:

PubMed: (ethics[MeSH] OR ethics[tiab]) AND (aborted fetus[MeSH] OR aborted fetus[tiab]) AND research, with a filter of Humans.

Web of Science, Scopus, and CiNii: ethics AND aborted fetus AND research AND human.

Japana Centra Revuo Medicina: ((ethics/TH OR ethics/AL) AND (aborted fetus/TH OR aborted fetus/AL) AND (research/TH OR research/AL) AND 
(CK=human).

We searched for reports from various committees and research groups from the Ministry of Health, Labour and Welfare (MHLW) and domestic books about this issue.

The search period was from 1973 to 2019.

\section{RESULTS}

PubMed, Web of Science, Scopus, Japana Centra Revuo Medicina, and CiNii showed 276 hits, 9 hits, 255 hits, 14 hits, and 18 hits, respectively. Excluding duplicates, there were 335 papers from the world (excluding Japan) and 31 papers from Japan. Although there were two peaks of overseas reports around 1975 and around 1990, there was a gently sloping peak of Japanese reports around 2005 (Figure 1). There were three reports from various committees and research groups from the MHLW and one domestic book about this issue, named "Abandoned life, utilized life". ${ }^{10}$

The two peaks observed overseas reflected the dates of the Peel Code and Polkinghorne Report, restrictively. The background behind the convergence of the two peaks seemed to be the development of fertility treatment technology and stem cell technology. Japan lacks the tendency to face and discuss such ethical issues properly, 
such as artificial abortion and fetal clause. Discussions were temporarily commenced by only one politician.

\section{The history of fetal tissue research and transplants}

The main research fields that utilize human fetuses are fetal cell transplantation, vaccine development, and basic biology. ${ }^{11}$

The first report about research use of human fetus was in 1922. Hurst et al. attempted a fetal adrenal graft transplantation in a patient of Addison's disease with severe anemia. ${ }^{12}$ Although many researchers including Hurst had been trying human fetal cell transplantation for several diseases since then, all of them failed for about half a century. In the 1980s, successful reports of fetal neural cell transplantation into Parkinson's disease patients occurred in many countries. ${ }^{13,14}$ It should be noted that the number of fetuses used to treat one patient ranged from one to dozens, and that there was no clear evidence for fetal cell transplantation treatment. So far, transplantation treatment using fetal tissues has been performed for various diseases, such as diabetes mellitus, ${ }^{15}$ various immunodeficiency syndromes, ${ }^{16,17}$ Alzheimer's disease, ${ }^{18}$ spinal cord injury, ${ }^{19}$ cerebral infarction, ${ }^{20}$ aplastic anemia, ${ }^{21}$ thalassemia, ${ }^{22}$ retinal degeneration ${ }^{23}$ and 22q11.2 syndrome, ${ }^{24}$ but none of these has become a standard treatment at this time. 
Vaccine development is another important field in human fetal research, which started around 1950. Not only because the immune system of humans differs from that of experimental mice ${ }^{25}$ but also because some pathogens such as human immunodeficiency virus (HIV) infect only humans, ${ }^{26}$ human cells were necessary to develop some vaccines. Vaccines such as M-M-R-II for rubella, VARIVAX for varicella, and HAVRIX for hepatitis A were manufactured using cell lines derived from human fetal tissues. ${ }^{27}$ On the other hand, some humanized mouse models using human fetal tissues were made to develop other vaccines. ${ }^{28}$ BLT mice, generated by human fetal liver and thymic tissue co-implantation under the kidney capsule using special techniques, were used for studies on many types of pathogens, such as HIV and Epstein-Barr virus (EBV). Now, no vaccines are produced using fresh aborted fetal tissue, but a few vaccines are still made using fetal cell lines, which were established years ago.

Basic biological research using aborted fetuses started in earnest around 1950. It is not an exaggeration to say that research use of aborted fetuses contributed to the development of various fields such as human development, pathophysiology, genetic diagnosis, and viral isolation. In Japan, the Kyoto Collection of Human Embryo, started in 1961, is a human germinal morphogenesis database that consists of more than 40,000 
specimens. $^{29,30}$

In order to support these studies, a fetal tissue bank was established at the United Kingdom in the $1950 \mathrm{~s}^{31}$ and an organization called Planned Parenthood Federation of America (PPFA) has been working in the United States to provide artificial aborted fetal tissue to researchers for a fee. ${ }^{32}$

\section{World history of restrictions on the use of fetal tissue (Table 1)}

Historically, the first guideline issued for research use of fetal tissue is the Peel Code in the United Kingdom in $1972 .{ }^{33}$ This code is a prototype for many rules and guidelines throughout the world, regarding the use of human fetal tissue for research and treatment purposes. It declares the following:

1. If the fetus is viable after separation from the mother, it is unethical to conduct any experiment inconsistent with the procedures necessary to keep the fetus alive.

2. The minimum survivability limit for a human fetus should be 20 weeks of gestation. This corresponds to approximately 400 - 500 grams.

3. The use of whole dead fetuses or tissues from dead fetuses for medical research is allowed on the condition that: 
(i) If the provisions of the Human Tissue Act apply, they will be observed.

(ii) If the provisions of the Human Tissue Act do not apply, there is no objection to parents who have the opportunity to demonstrate hope regarding the disposal of the fetus.

(iii) No autopsies on dead fetuses or no experiments on fetuses or fetal samples are performed in the operation room or the delivery room.

(iv) No financial exchange for fetuses or fetal samples exists.

(v) Full records are stored in appropriate facilities.

4. Use of the entire fetus before being viable is allowed under the following conditions:

(i) The conditions of clause three are observed.

(ii) Only fetuses weighing less than 300 grams are used.

(iii) The responsibility to determine that the fetus can be used for research is never the researcher, but the healthcare provider involved in childbirth.

(iv) Such studies are conducted only in departments directly related to the hospital and require direct approval from the ethics committee.

(v) Before such research is approved, the ethics committee needs to 
consider the validity of the research, the availability of alternatives, and the skills required for researchers.

5. It is unethical to intentionally administer drugs or perform treatments during pregnancy with the intention of confirming harm to the fetus.

After the Peel Code, the Polkinghorne Report on fetal research was issued in 1989. ${ }^{34}$ This is also an implementation rule that is frequently cited in other guidelines. Its content consists of the following:

1. Fetal treatment

1.1 There are two categories in fetuses:

(a) Alive fetuses either in utero or ex utero, should be treated by the principle similar to treatments or researches for children or adults.

(b) Dead fetuses. (Partially omitted) Only tissues from dead fetuses can be used for treatment ethically.

1.2 It is unethical to administer drugs or undergo procedures during pregnancy with an intention of ascertaining whether it will harm the fetus during pregnancy.

1.3 For neural tissue, only isolated neurons or tissue fragments should be used for transplantation. 
2. Uterine contents other than the fetus can be used for examination, research or treatment in a certain condition.

3. Research and treatment practices must be separated from the supply of fetal tissues.

4. Informed consent to the mother not to the father is required. Consent for termination of pregnancy should be taken before the consent for use of fetal tissues.

5. No nursing staff should be obliged to participate in research or treatment on the fetus or fetal tissue if he or she has a conscientious refusal.

6. Any innovative research or treatment, including the fetus or fetal tissue, should be documented in the protocol and considered by the ethics committee.

7. Money transfer to fetus or fetal tissue is prohibited.

Not only the Peel Code but also the Polkinghorne Report were constructed in the United Kingdom. Looking around the world, at around the same time, the World Medical Association (WMA) released a "Statement on fetal tissue transplantation" and the International Federation of Gynecology and Obstetrics (FIGO) released "Guidelines 
for the use of embryonic or fetal tissue for therapeutic clinical applications”, but their contents were almost the same as the Polkinghorne Report.

Europe is the most regulated area on this issue in the world. The Network of European Central Nervous System Transplantation and Restoration (NECTAR) released "Ethical guidelines for the use of human embryonic or fetal tissue for experimental and clinical neurotransplantation and research” in $1994 .^{35}$ This guideline defines what to do in detail, as follows:

1. Death before use

2. No artificial rearing

3. No link with decision on termination of pregnancy

4. "Non-maleficence" of retrieval methods

5. Consent of the woman

6. Consent for tests of transmissible diseases

7. Brain fragments only

8. Complete information for personnel involved

9. No profit and remuneration

10. Application to medical-ethics committees

In Sweden, the Transplantation Act (1995) restricts research use of fetal tissues 
with penalties. In Sweden, medical researchers need to get agreement from the mother and permission from Socialstyrelsen in order to use fetal tissues. Aborted fetal tissues are only permitted to use in medical purpose. Transplantation of organs and other biomaterials is performed at government-designated medical institutions in Sweden. Final decision of performing organ transplantation is made by the clinician who is ultimately responsible for that procedure. We could say that once the protocol of research has been permitted by Socialstyrelsen, Sweden is one of the freest countries in the world for research use and clinical use for aborted fetal tissues. ${ }^{36}$

In Germany, the Embryo Protection Act (1990) strictly prohibits the usage of surplus embryos for research. In 1991, the German Medical Association (GMA) released "Guidelines on the use of fetal tissue and fetal cell". In this guideline, the use of aborted fetuses was permitted and the necessity of non-profit organization banks was declared. ${ }^{37}$ In 1998, the GMA Central Ethics Committee prohibited the usage of fetal neural cells for Parkinson's disease patient's brain. ${ }^{38}$

Only Spain and the Netherlands have independent laws on the use of fetal tissue, but they were established around 20 to 30 years ago and have not been revised since then. Since new technologies and new problems (i.e. generation of embryonic germ cells from aborted fetuses, cloning technology and genome editing technology) are 
evoking around this matter, it seems to be time for consideration of revision.

In Spain there is a law named "Donation and utilization of human embryos and fetuses or their cells, tissues or organs” declared at $1988 .{ }^{39}$ This law consists of following clauses:

1. General remarks

2. Measures for embryos and fetuses

3. Research, experiment and genetic technology

4. Violations and penalties

In Netherlands there is a law named "Foetal Tissue Act" declared at $2001 .^{40}$ It consists of the followings:

1. Definition of words

2. Permitted purpose for the conservation and usage of fetal tissues

3. Informed consent to the mother and the father

4. The timing of information and consent for research use of fetal tissues

5. Acquisition and withdrawal of consent

6. Implementation code

7. Conservation and traceability of fetal tissues

8. Supervision of compliance 
9. Prohibition of sending and receiving money

10. Prohibition of making offspring from fetus

11. Cell lines and cell cultures

12. Prohibition of tissue removal from live fetuses

13. Penalties

14. Elimination of prohibition of transplantation

No country completely prohibits the research use of fetal tissue.

In the United States, the "Uniform Anatomical Gift Act” enacted in 1968 stated that dead fetuses can be used for research if compliance from either of the fetal parents is obtained. ${ }^{41}$ In 1974 the "National Research Act (Public Law 93-348)" was enacted in order to establish basic ethical principles for human subject research. ${ }^{42}$ Debates on fetal research were conducted actively in the 1970s, and the anti-abortionist movement became very vocal in the 1980s. In 1988 the Health and Human Services decided to prohibit federal funding for transplantation research using aborted fetal tissue for a period, the so-called "moratorium declaration of aborted fetal tissue transplantation research". ${ }^{43}$ The moratorium era ended in 1992, when the fetal tissue bank was established in the United States. ${ }^{44}$ After 1993, the moratorium was canceled, and research on aborted fetal tissue came to notice again. Discussion about the permitted 
condition of fetal tissue use is lacking in the United States. Code of Federal Regulation describes that research shall be conducted only in accord with any applicable federal, state, or local laws and regulations regarding such activities. ${ }^{45}$ So, National institutes of health (NIH) and research ethics committee are reviewing each case according to the laws and regulations of each state.

\section{The history of restrictions on the use of fetal tissue in Japan (Table 1)}

Legal and ethical regulations regarding the handling of human aborted fetuses in Japan comprise the Penal Code, the Maternal Health Act, the Autopsy Law, and ordinances of each local government, but there is no special provision for research use of aborted fetuses. The Autopsy Law describes the handling of corpses of fetuses older than four months of pregnancy, but no provisions for fetuses younger than four months exist.

The Japan Society of Obstetrics and Gynecology issued in 1987 "a view on the pros and cons of using dead organs of dead fetuses and newborn babies for research". ${ }^{46}$ The following four requirements were presented in this view.

1. To follow the preservation method of the corpse

2. That there is no method other than using aborted fetus, and the expected 
research results are extremely large

3. That those who perform research use of fetuses should be doctors in principle

4. That privacy is obtained by informed consent from the parents

This view with no legal binding force is made by an academic society only for obstetricians and gynecologists, and no restrictions on the relationship with the researcher is described. The emergence of unauthorized facilities in noninvasive prenatal genetic testing (NIPT) shows how powerless the guidelines of a non-legal binding society are. ${ }^{47}$

In order to create a guideline for research usage of stem cells which are provided from fetal tissues, "Special Committee on the State of Clinical Research Using Human Stem Cells” was held between 2001 to $2005 .{ }^{48}$ In this committee, discussion was undergone on research use of aborted fetuses, but not on artificial abortion itself. An agreement was reached to allow the use of aborted fetuses under strict conditions, and it was advanced to the stage where the details of guidelines were finalized. However, the committee concluded that the research use of human aborted fetus should be refrained from because of poor public understanding in the end. ${ }^{48}$ One of the reasons for this was that a broadcast in 2004 showed a maternity clinic in Yokohama throwing away 
dead fetuses as general waste, leading the public opinion to opposition to artificial abortion itself. In the "Guideline on clinical research using human stem cells" (announced in 2010), Clinical research using human stem cells collected from the fetus (including dead fetuses) was excluded from the subject.

A "Study on the role of human fetal tissue supply system and the role of fetal tissue donor coordinator" (2003-2004) was held almost at the same time, but it concluded that comprehensive rules, which cover the whole research use of human fetal tissue, and that original regulation as an expert group should be created. ${ }^{49}$ However, nothing is discussed about this issue after that, partly due to the public opinion against artificial abortion itself.

Looking at other guidelines in Japan, there is no description about the usage of aborted fetal tissues in the "Ethical guidelines for human genome and genetic sequencing research" (conducted in 2001; revised in 2017), the "Guideline on ethical issues in application of human tissue to medical practice" (conducted in 2002; revised in 2010), the "Ethical guidelines on clinical research" (conducted in 2003; revised in 2008), or in the "Ethical guidelines for medical and health research involving human subjects" (conducted in 2015; finally revised in 2017).

At the legislature, "Technical committee on the ideal way of clinical research 
using human stem cells” was held around 2000. Renko Kitagawa played an important role in this committee, but was defeated in the 2003 lower house general election. After that, no discussion is held for this issue at the legislature until now. ${ }^{50}$

When considering the ethical problem of using dead fetuses, the problem of artificial abortion is inevitable. Around 2000, various discussions on research use of dead fetuses took place in Japan avoiding argument about propriety of artificial abortion, but with public opposition to artificial abortion, all the discussions concluded the direction of research denial.

\section{Legal/ethical problems in the research use of the tissues of aborted human fetuses}

We have described the historical background and current situation in Japan and overseas regarding this issue. We would like to extract and summarize the legal/ethical problems in research use of human fetal tissues below. ${ }^{7}$

First, some women may plan pregnancy and commercial selling of fetal tissues assuming usage of fetuses after abortion. Therefore, decision of abortion and explanation of use of fetal tissues after abortion must be separated, and money transfer to women and designation of recipients by women are prohibited. Although these restrictions may not be enough to prevent planned pregnancy for fetal selling, there is 
no effective way to prevent commercial selling of fetuses.

Second, acceptance of the use of aborted fetuses may affect decision making of abortions, which may lead to increase in number of abortions. It is very difficult to suppress this action when abortion is considered a woman's right.

Third, fetuses lacking consent are donors, and it is very difficult to guarantee the quality of informed consent by the surrogates, usually the woman and the partner.

Fourth, there is no answer to the debate about whether the fetus is human being or not, when the fetus will become a human being, and whether the fetus has a personality.

These four problems may evoke not only in Japan but throughout the world. There are also some problems peculiar to Japan. When organ transplantation is performed in Japan, the Organ Transplant Law is applied. Until the law was revised in 2010, in order to perform fetal tissue transplantation, consent of not only the person but also the bereaved was necessary, and there were only few children donors by that time. Even after the law has been amended to allow organ transplantation from children, the society must discuss properly about organ transplantations from aborted fetuses. 


\section{DISCUSSION}

We have organized the domestic and international history of research use of aborted fetal tissue and have described the current problems. It has become clear that legislation is inadequate not only in Japan but also overseas. Although it is an issue that requires careful ethical consideration, there are important studies that require human fetal tissue. Studies with human fetal tissue are still being conducted elsewhere in the world, escaping legal restrictions. It is important to establish laws and guidelines, while ensuring transparency and gaining public understanding.

Since there is significant difference in the way of thinking between Japan and other countries, local considerations are needed. In Japan there is a tendency to obscure rules or guidelines and prevent discussions, but internationally there is a tendency to accept research within a limited range under proper rules. Japanese-natured way of thinking is making it difficult to argue about this issue.

Most of the human fetal tissues used in medical studies are obtained by artificial abortion. Before we debate about research use of human fetal tissue, we cannot avoid discussion about the propriety of artificial abortion. Although the propriety of artificial abortion is not a main point of our paper, we want to discuss about it in the following paragraph. 
From when human rights exist in the fetus is an eternal theme that has been debated for a long time throughout the world. A women's right to undergo abortion and the fetal right to survive make a parallel line, leading to no conclusion. In Japan, artificial abortion is allowed only when the gestational age is less than 22 weeks. Since the human fetus up to around 12 weeks of gestation is structurally and functionally incomplete, so-called the "organogenetic stage", registrations of stillbirth and burials are required only for abortions at or after 12 weeks of gestation, and 94\% of the artificial abortion is carried out by the end of the 11 th week of pregnancy. ${ }^{9}$ These facts may be based on the idea that the human fetus in the period of organogenesis has no human rights. Moreover, there is no provision for so-called fetal indication ("Embryopathic Indication") in Japan. Although the fetal clause has been discussed several times in Japan, no conclusion has been reached yet. Although artificial abortion due to fetal abnormalities is prohibited legally, it has been taking place by the indication of maternal health under special interpretation of the Maternal Health Act in Japan. This means that nurturing a handicapped baby may harm maternal health economically. It may be time to seriously argue about abortion while gaining public understanding. When discussing artificial abortion, various issues such as religious opinions and women's rights are involved, making the problem more complex. This is a common issue throughout the 
world, not only in Japan.

When discussing the evolution of science and its regulation, professional autonomy should be respected at first. Although it is an ideal world when all scientists follow their autonomy and causes no trouble, such situations are extremely rare. Second, several international documents and/or guidelines would develop for regulation of science. Since documents or guidelines are not legally binding, some researchers may not follow them. In such situations, establishing international laws is essential for the balance of development and regulation of science.

Stem cell research is progressing rapidly while under strict legal regulations. When a new technology is developed to circumvent current legislation, legal regulations will be strengthened in stem cell research. Despite the use of the same fetal cells, strict regulations have been made on the study of ES cells, but little has been done on the research use of the tissues of aborted human fetuses. It might be time to set an international law for research use of human fetal tissue, based on the Peel Code and the Polkinghorne Report, which are widely accepted in many countries’ laws or guidelines. Since there is currently no international rule about the research use of aborted fetuses, the ethics committee of each institution plays an especially important role now and conducts its own examination. Establishing an international rule can lead to fairness in 
examinations of each ethics committee. Moreover, since there are many people who are negative about the research use of fetal tissues, establishing an international rule is indispensable for actively promoting their research use. Without international laws, researchers who are low awareness of ethics may conduct inadequate research in countries where laws are not in place. Since the world has become closer in time and space compared to the past, researchers may choose to study in countries with less restrictions on their research. In 2018, He Jiankui underwent human germline genome editing using the CRISPR-Cas9 technology, which became a big social issue. If legislation is inadequate, similar problems may occur in the future. ${ }^{51}$ Therefore, we think it is necessary to create rules that are common throughout the world.

It is time to discuss properly about the research use of aborted fetuses, separate from the discussion of the propriety of artificial abortion; but in Japan this discussion often results in sentiment with no progression eventually. Japanese public opinion is chilly, and if something goes wrong, it can be highly criticized. The judiciary as well as the legislation tend to avoid these ethical issues. Furthermore, Japan is traditionally a vertically divided society, making it difficult to discuss this type of issues and to develop comprehensive laws across multiple ministries. No political party has ever had a prominent discussion on this issue, and the fact that it is entrusted to the power of 
individual members of the parliament is one of the factors that keep the discussion from progressing.

Research use of human aborted fetuses began almost a century ago without any legal regulation. Among the peculiarities of artificial abortion being socially accepted, there is relatively little opportunity for it to be mentioned and discussed, and various studies are still being conducted. There are many strict regulations on the creation and usage of human fertilized embryos for research purposes, such as the Human Fertilization and Embryology Act in the United Kingdom, the Bioethics Law in France, the Human Embryo Protection Act in Germany, and Bioethics and Safety Act in Korea. The development of laws and guidelines on research use of the tissues of aborted human fetuses is insufficient not only in Japan but also around the world.

\section{DISCLOSURE}

None of the authors have conflict of interest to declare. 


\section{REFERENCES}

1. Enosawa S. Present status and problems in research use of human fetus [in Japanese]. Organ Biology. 2005;12(2):155-66.

2. O'Rahilly R, Müller F. Developmental stages in human embryos: including a revision of Streeter's "Horizons" and a survey of the Carnegie collection. Washington, D.C.: Carnegie Institution of Washington; 1987.

3. Kyoto Human Embryo Visualization Project [Available from: http://bird.cac.med.kyoto-u.ac.jp/index_e.html.

4. Harrison T, Graham F, Williams J. Host-range mutants of adenovirus type 5 defective for growth in HeLa cells. Virology. 1977;77(1):319-29.

5. JCRB Cell Bank: National Institutes of Biomedical Innovation, Health and Nutrition; [Available from: https://cellbank.nibiohn.go.jp/ cellbank/en/search_res_list_combi.cgi.

6. Hammerman MR. Classic and current opinion in embryonic organ transplantation. Current opinion in organ transplantation. 2014;19(2):133-9.

7. Mori Y. Ethical issues surrounding tissue use of dead fetuses [in Japanese]. Journal of medicine, life and ethics, society. 2003;2(2):6-12. 
8. Lindvall O. Treatment of Parkinson's disease using cell transplantation. Philosophical transactions of the Royal Society of London Series B, Biological sciences. 2015;370(1680):20140370.

9. 2017 hygiene administration report: statistics table, annual report [in Japanese]. In: Ministry of Health, Labour and Welfare, editor. 2018.

10. Tamai M, Hiratsuka S. Abandoned life, used life [in Japanese]: Seikatsu-shoin; 2009.

11. Gelber SE, McCullough LB, Chervenak FA. Fetal tissue research: an ongoing story of professionally responsible success. Am J Obstet Gynecol. 2015;213(6):819.e1-4.

12. Hurst AF, Tanner WE, Osman AA. Addison's Disease, with Severe Anaemia, treated by Suprarenal Grafting. Proc R Soc Med. 1922;15(Clin Sect):19-20.

13. Lindvall O, Brundin P, Widner H, Rehncrona S, Gustavii B, Frackowiak R, et al. Grafts of fetal dopamine neurons survive and improve motor function in Parkinson's disease. Science. 1990;247(4942):574-7.

14. Freed CR, Zhou W, Breeze RE. Dopamine cell transplantation for Parkinson's disease: the importance of controlled clinical trials. Neurotherapeutics: the journal of the American Society for Experimental NeuroTherapeutics. 
2011;8(4):549-61.

15. Fichera G. Impianti omoplastici feto-umani nel cancro e nel diabete. Tumoi. 1928;14:434.

16. Seto S, Miyake T, Hirao T. An engraftment case of fetal liver cell transplantation in severe combined immunodeficiency [in Japanese]. Clin Immunol. 1983;15(2):155-65.

17. Higuchi S, Yanagibe Y, Nakamura T, al. e. Therapeutic effects of thymic hormone and radiation treated fetal thymus transplantation in a male case of immunodeficiency with $\mathrm{T}$ cell reduction [in Japanese]. Pediatrics of Japan. 1991;32(8):851-8.

18. Li YJ, Conrad JA, Low WC. Transplantation of cholinergic-rich spinal tissue from spontaneously aborted human fetuses into a rodent model of Alzheimer's disease. Transplantation proceedings. 1994;26(6):3336-7.

19. Liang P, Liu J, Xiong J, Liu Q, Zhao J, Liang H, et al. Neural stem cell-conditioned medium protects neurons and promotes propriospinal neurons relay neural circuit reconnection after spinal cord injury. Cell transplantation. 2014;23 Suppl 1:S45-56.

20. Borlongan CV, Koutouzis TK, Jorden JR, Martinez R, Rodriguez AI, Poulos 
SG, et al. Neural transplantation as an experimental treatment modality for cerebral ischemia. Neuroscience and biobehavioral reviews. 1997;21(1):79-90.

21. Sharma S, Patil HP. Acute undifferentiated leukaemia in a patient of aplastic anaemia treated with foetal liver infusions. The Journal of the Association of Physicians of India. 1992;40(5):337-8.

22. Touraine JL. In utero transplantation of fetal liver stem cells into human fetuses. Journal of hematotherapy. 1996;5(2):195-9.

23. Litchfield TM, Whiteley SJ, Lund RD. Transplantation of retinal pigment epithelial, photoreceptor and other cells as treatment for retinal degeneration. Exp Eye Res. 1997;64(5):655-66.

24. August CS, Rosen FS, Filler RM, Janeway CA, Markowski B, Kay HE. Implantation of a foetal thymus, restoring immunological competence in a patient with thymic aplasia (Digeorge's syndrome). Lancet. 1968;2(7580):1210-1.

25. Mestas J, Hughes CCW. Of Mice and Not Men: Differences between Mouse and Human Immunology. The Journal of Immunology. 2004;172(5):2731-8.

26. Woolhouse M, Scott F, Hudson Z, Howey R, Chase-Topping M. Human viruses: discovery and emergence. Philosophical transactions of the Royal 
Society of London Series B, Biological sciences. 2012;367(1604):2864-71.

27. McKenna KC. Use of Aborted Fetal Tissue in Vaccines and Medical Research Obscures the Value of All Human Life. The Linacre quarterly. 2018;85(1):13-7.

28. Akkina R. Human immune responses and potential for vaccine assessment in humanized mice. Current opinion in immunology. 2013;25(3):403-9.

29. Yamada S, Samtani RR, Lee ES, Lockett E, Uwabe C, Shiota K, et al. Developmental atlas of the early first trimester human embryo. Developmental dynamics: an official publication of the American Association of Anatomists. 2010;239(6):1585-95.

30. Shiota K. Study of Normal and Abnormal Prenatal Development Using the Kyoto Collection of Human Embryos. Anatomical record (Hoboken, NJ: 2007). 2018;301(6):955-9.

31. Kay HE, Constandoulakis M. A foetal tissue bank; problems and prospects. British medical journal. 1959;1(5121):575-8.

32. Wadman M. The truth about fetal tissue research. Nature. 2015;528(7581):178-81.

33. The Use of Fetuses and Fetal Material for Research, Report of the Advisory Group. Department of Health and Social Security 1972. 
34. Review of the Guidance on the Research Use of Fetuses and Fetal Material. Her Majesty’s Stationery Office 1989.

35. Boer GJ. Ethical guidelines for the use of human embryonic or fetal tissue for experimental and clinical neurotransplantation and research. Network of European CNS Transplantation and Restoration (NECTAR). Journal of neurology. 1994;242(1):1-13.

36. Hishiki S. Transplantation Act in Sweden [in Japanese]. Kokushikan comparative law review. 1997; 20:101-135.

37. Bundesärztekammer B. Richtlinien zur Verwendung fetaler Zellen und fetaler Gewebe [in German]. Dtsch Arztebl. 1991;88(48): A-4296.

38. Bundesärztekammer ZEbd. Übertragung von Nervenzellen in das Gehirn von Menschen. Deutsches Ärzteblatt. 1998;95(30): A1869-A71.

39. Mahowald MB. Placing wedges along a slippery slope: use of fetal neural tissue for transplantation. Clinical research. 1988;36(3):220-2.

40. Gold RB, Lehrman D. Fetal research under fire: the influence of abortion politics. Family planning perspectives. 1989;21(1):6-11, 38.

41. Mahowald MB. Placing wedges along a slippery slope: use of fetal neural tissue for transplantation. Clinical research. 1988;36(3):220-2. 
42. National Research Act—conference report. Congressional record: proceedings and debates of the ... Congress. United States. 1974;120(95):S11776-11785.

43. Gold RB, Lehrman D. Fetal research under fire: the influence of abortion politics. Family planning perspectives. 1989;21(1):6-11, 38.

44. Hilts P. Fetal tissue bank can not meet goal, agency memo says: Bush proposal is faulted. New York Times. 19921992 July 27.

45. Code of Federal Regulations Title 45: Public welfare Part 46: Protection of human subjects, Department of Health and Human Services; 2009.

46. Iiduka R. A view on the pros and cons of using dead organs of dead fetuses and newborn babies for research [in Japanese]. 1987 Jan, 1987.

47. Yamada T, Sekizawa A, Fujii Y, Hirose T, Samura O, Suzumori N, Miura K, Sawai H, Hirahara F, Murotsuki J, Kamei Y, Sago H; Japan NIPT consortium*. Maternal age-specific risk for trisomy 21 based on the clinical performance of NIPT and empirically derived NIPT age-specific positive and negative predictive values in Japan. J Hum Genet. 2018;63(10):1035-1040.

48. Proceedings of the special committee on the state of clinical research using human stem cells [in Japanese]. 25th meeting of the special committee on the state of clinical research using human stem cells; 2006 Feb 22, 2006: Science 
and Technology Committee of Health Sciences Council.

49. Tamai M, editor General research report of the research on the way of human fetal tissue supply system and the role of fetal tissue donor coordinator [in Japanese]. Human genome and regenerative medicine research projects; 2005 March 2005: Ministry of Health, Labour and Welfare.

50. Kurihara C, Matsumoto K, Saio T. Reflections on fetal transplantation: overview and proposal [in Japanese]. Clin Eval. 2004;32(21):85-148.

51. Greely, HT. CRISPR'd babies: human germline genome editing in the 'He Jiankui affair'. J Law Biosci. 2019;6(1):111-183. 


\section{FIGURE LEGENDS}

Figure 1. The result of literature searches of Japan and the World, with a historical timeline of cell research studies. 
Peel Code (1972 U.K.)

Roe v. Wade (1973 U.S.)

First IVF baby born (1978)

First generation of mouse ES cells (1981)

Temporary moratorium (1988-1993 U.S.)

Polkinghorne Report (1989 U.K.)

First generation of artificial animal clones (1997)

First generation of human ES cells and EG cells (1998)

First generation of mouse iPS cells (2006)

First generation of human iPS cells (2007)

Nobel prize to Evans M., Capecchi M. and Smithies O. (2007)

Nobel prize to Gurdon J. and Yamanaka S. (2012)

First clinical trial using iPS cells (2014) 
Table 1. Major restrictions on the use of human fetal tissue

\begin{tabular}{|c|c|}
\hline Countries & Guidelines, reports and recommendations \\
\hline Global & $\begin{array}{l}\text { Statement on Fetal Tissue Transplantation (1989) by the World Medical Association } \\
\text { Guidelines for the Use of Embryonic or Fetal Tissue for Therapeutic Clinical Applications } \\
\text { (1992) by the International Federation of Gynecology and Obstetrics }\end{array}$ \\
\hline United States & $\begin{array}{l}\text { Uniform Anatomical Gift Act (1968) } \\
\text { National Research Act (Public Law 93-348) (1974) } \\
\text { Report and Recommendation: Research on the Fetus (1975) } \\
\text { Report of the Human Fetal Tissue Transplantation Research Panel (1988) } \\
\text { by the National Institutes of Health } \\
\text { Moratorium declaration of aborted fetal tissue transplantation research (1988) } \\
\text { Medical Applications of Fetal Tissue Transplantation (1990) } \\
\text { by the American Medical Association } \\
\text { The National Institute of Health Revitalization Act (1993) } \\
\text { Code of Federal Regulation } 45 \text { Part } 46 \text { (2001) } \\
\text { Current opinions of the Council on Ethical and Judicial Affairs, Fetal Research Guidelines } \\
\text { (2002) by the American Medical Association }\end{array}$ \\
\hline Europe & $\begin{array}{l}\text { On the use of human embryos and fetuses for diagnostic, therapeutic, scientific, industrial } \\
\text { and commercial purposes (1986) by the Parliamentary Assembly of the Council of } \\
\text { Europe } \\
\text { Report on scientific research relating to the human embryo and foetus (1988) by the } \\
\text { Parliamentary Assembly of the Council of Europe, Committee on Science and } \\
\text { Technology } \\
\text { On the use of human embryos and fetuses for scientific research (1989) } \\
\text { by the Parliamentary Assembly of the Council of Europe } \\
\text { Ethical guidelines for the use of human embryonic or fetal tissue for experimental and } \\
\text { clinical neurotransplantation and research (1994) by the Network of European Central } \\
\text { Nervous System Transplantation and Restoration (NECTAR) } \\
\text { Ethical guidance on the use of human embryonic and fetal tissue transplantation (2002) by } \\
\text { the EC BIOMED Project }\end{array}$ \\
\hline United Kingdom & $\begin{array}{l}\text { The use of fetuses and fetal material for research, report of the advisory group (the Peel } \\
\text { Code) (1972) by the Department of Health and Human Services } \\
\text { Guidelines on the use of fetal tissue (1988) by the British Medical Association } \\
\text { Review of guidance on the research use of fetuses and fetal material (the Polkinghorne } \\
\text { report) (1989) by the Department of Health and Human Services } \\
\text { Guidance on the use of foetal tissue research, diagnosis and therapy (1995) } \\
\text { by the Department of Health and Human Services } \\
\text { Human Bodies, Human Choices -the law on human organs and tissue in England and }\end{array}$ \\
\hline
\end{tabular}




\begin{tabular}{|c|c|}
\hline & Wales, a consultation report (2002) by the Department of Health \\
\hline France & $\begin{array}{l}\text { Opinion on sampling of dead human embryonic and foetal tissue for therapeutic, } \\
\text { diagnostic, and scientific purposes (1984) } \\
\text { Opinion on the establishment of collections of human embryo cells and their use for } \\
\text { therapeutic or scientific purposes (1997) } \\
\text { Opinion on the preliminary draft revision of the laws on bioethics (2001) }\end{array}$ \\
\hline Germany & $\begin{array}{l}\text { Guidelines on the use of fetal tissue and fetal cell (1991) by the German Medical } \\
\text { Association } \\
\text { Transplanting neurons into the human brain: Opinion of central ethics committee in the } \\
\text { German Medical Association (1998) }\end{array}$ \\
\hline Netherlands & $\begin{array}{l}\text { Advice on donation and use of fetuses, fetal tissue and other remains of abortion for } \\
\text { scientific purposes (1984) } \\
\text { Dutch Committee on Ethical Aspects of Medical Research, Annual Report } 1991 \text { and } 1992 \\
\text { (1993) } \\
\text { Foetal Tissue Act (2001) }\end{array}$ \\
\hline Switzerland & $\begin{array}{l}\text { Medical-ethical guidelines for the transplantation of human foetal tissue (1998) by the } \\
\text { Swiss Academy of Medical Sciences }\end{array}$ \\
\hline Sweden & $\begin{array}{l}\text { Guiding Principles for the Use of Fetal Tissue in Clinical Transplantation Research (1990) } \\
\text { Transplantation Act (1995) }\end{array}$ \\
\hline Spain & $\begin{array}{l}\text { Law } 42 \text { on Donation and Utilization of Human Embryos and Fetuses or of their Cells, } \\
\text { Tissues or Organs (1988) }\end{array}$ \\
\hline Australia & $\begin{array}{l}\text { Statement on Human Experimentation and Supplementary Notes (1992) } \\
\text { by the National Health and Medical Research Council }\end{array}$ \\
\hline Japan & $\begin{array}{l}\text { A view on the pros and cons of using dead organs of dead fetuses and newborn babies for } \\
\text { research (1987) by the Japan Society of Obstetrics and Gynecology }\end{array}$ \\
\hline
\end{tabular}

